\title{
Occurrence of multidrug resistant Escherichia coli in groundwater of Brij region (Uttar Pradesh) and its public health implications
}

\author{
Barkha Sharma ${ }^{1}$, Parull ${ }^{2}$ A. K. Verma ${ }^{1}$, Udit Jain ${ }^{2}$, Janaradan K. Yadav², Ravneet Singh ${ }^{2}$ and Raghvendra Mishra ${ }^{2}$
}

1. Department of Epidemiology and Preventive Veterinary Medicine, College of Veterinary Science and Animal Husbandry, UP Pt Deen Dayal Upadhyay Veterinary University, Mathura - 281 001, Uttar Pradesh, India; 2. Department of Veterinary Public Health, College of Veterinary Science and Animal Husbandry, UP Pt Deen Dayal Upadhyay Veterinary University, Mathura - 281001 , Uttar Pradesh, India.

Corresponding author: Barkha Sharma, e-mail: manubarkha@yahoo.com,

Co-authors: P: parulkaler@rediffmail.com, AKV: drakverma79@gmail.com, UJ: druditjain@hotmail.com, JKY: janardanyadav1987@gmail.com, RS: dr.ravneet_singh@live.com, RM: rmishra523@rediffmail.com Received: 24-10-2016, Accepted: 26-01-2017, Published online: 10-03-2017

doi: 10.14202/vetworld.2017.293-301 How to cite this article: Sharma B, Parul, Verma AK, Jain U, Yadav JK, Singh R, Mishra R (2017) Occurrence of multidrug resistant Escherichia coli in groundwater of Brij region (UP) and its public health implications, Veterinary World, 10(3): 293-301.

\begin{abstract}
Aim: The study evaluates the microbial as well as physicochemical pollution of groundwater of Brij region of Uttar Pradesh, a major tourist destination in the country along with estimating the drug resistance evident in the isolated Escherichia coli.

Materials and Methods: A total of 60 samples of groundwater were collected from six different sites and assessed for physicochemical ( $\mathrm{pH}$, color, taste, turbidity, total dissolved solids [TDS], total hardness [TH], chlorides, fluorides, nitrates, and iron) and microbiological parameters (standard plate count [SPC], most probable number test [MPN], E. coli).

Results: A majority of the samples were found to be out of the range for most of the parameters except iron. Particularly, high values of TDS (up to $9000 \mathrm{ppm}$ ), TH $(1500 \mathrm{mg} / \mathrm{L})$, chlorides $(3250 \mathrm{mg} / \mathrm{L})$, fluorides $(2.5 \mathrm{mg} / \mathrm{L})$, and nitrates $(100.2 \mathrm{mg} / \mathrm{L})$ were observed at most of the sites in the region highlighting the fact that groundwater of the area is not potable. Samples were turbid and salty to taste. High SPC values, up to 3500 colony-forming unit $/ \mathrm{ml}$ and coliforms beyond BIS range were found in $40 \%$ samples suggesting gross microbial contamination. Only 2 sites (G3 and G5) had low MPN values. Overall $16(26.67 \%) E$. coli were isolated with $3(18.75 \%)$ producing red colonies on conge red agar, hence supposed to be pathogenic. No E. coli $\mathrm{O} 157: \mathrm{H} 7$ was isolated. High antimicrobial resistance was observed against amoxicillin and erythromycin, whereas $E$. coli isolates were sensitive toward cefotaxime-clavulanic acid and imipenem. 12 isolates (75\%) were multidrug resistant (MDR) with MDR index $>20 \%$, and 2 isolates (12.5\%) were found to be extended spectrum betalactamases positive.
\end{abstract}

Conclusion: Groundwater is considered to be a safe option for potable water but it is obvious from the findings of this study that considerable physicochemical and microbial contamination is there in groundwater samples of Brij region. The occurrence of MDR E. coli in these waters is a matter of great public health concern.

Keywords: groundwater, microbial analysis, multidrug resistant Escherichia coli, physicochemical analysis.

\section{Introduction}

Lack of safe drinking water and poor water sanitation is estimated to take a greater human toll than war, terrorism, and weapons of mass destruction combined. Waterborne diseases account for nearly 1.8 billion human deaths annually and $4.1 \%$ of the total disability-adjusted life years global burden of disease with $88 \%$ of it being attributable to unsafe water supply, sanitation and hygiene [1]. In 2011, around 768 million people in the third world countries of Asia and Africa relied on unsatisfactory water supply having high levels of pathogen contamination [2]. Not only developing countries but developed

\footnotetext{
Copyright: Sharma, et al. Open Access. This article is distributed under the terms of the Creative Commons Attribution 4.0 International License (http://creativecommons.org/licenses/ by/4.0/), which permits unrestricted use, distribution, and reproduction in any medium, provided you give appropriate credit to the original author(s) and the source, provide a link to the Creative Commons license, and indicate if changes were made. The Creative Commons Public Domain Dedication waiver (http:// creativecommons.org/publicdomain/zero/1.0/) applies to the data made available in this article, unless otherwise stated.
}

nations also see significant outbreaks of waterborne intestinal disease [3].

In many areas, groundwater (well water, submersible water, and handpump) remains the major source of drinking water for people as it is considerably free from impurities and less susceptible to contamination compared to surface water bodies. However, due to a variety of unscientific land and water-based human activities, development and over-exploitation, ground water quality is slowly but surely declining everywhere [4] causing either acute or chronic health effects [5]. Ground water pollution is difficult to detect, and the solutions are expensive, difficult to determine, hard to resolve, tedious and not always effective.

Monitoring the microbiological quality of drinking water relies mainly on the examination of indicator bacteria such as coliforms. Being prevalent in human and animal feces, E. coli appears to provide the best bacterial indication of fecal contamination in drinking water as it can be detected with the 
help of comparatively faster, sensitive, and affordable methods. Its presence in food or water strongly indicates the increased risk of the presence of foodborne pathogenic microbes [6]. Although E. coli is commensals of human intestinal tract, several E. coli clones have acquired specific virulence factors encoded by mobile genetic elements often located in the chromosomes on pathogenicity islands, not found in commensals [7-10]. Pathogenic E. coli strains generally cause three clinical syndromes: Enteric/diarrheal disease, urinary tract infection, and sepsis/ meningitis [11].

Antibiotic resistance against commonly used antibacterial agents is increasing due to the non-judicious use of antibiotics in human medicine, agriculture and veterinary fields, especially against beta-lactam drugs. Gram-negative bacteria are most prone as a result of their production of beta-lactamases. Extended spectrum beta-lactamases (ESBLs) have been generally defined as transmissible beta-lactamases that can be inhibited by clavulanic acid, tazobactum, or sulbactum and encoded by genes exchangeable between bacteria. There are more than 400 ESBLs described, clustered into nine different structural and evolutionary families derived from the mutants of temoneira and sulfhydryl variable enzymes and cefotaximase (type lactamases originating from beta-lactamases present in the genus "Kluyvera") [12].

Brij region (Mathura, Agra and surrounding areas) of Uttar Pradesh is a major tourist destination in India with lakhs of both foreign and domestic tourists visiting these places. At any given time, the floating population is much more than the actual people residing in this area. This creates added burden on the available water resources in the region which already faces considerable water problems. The majority of the population depends on groundwater sources for domestic and agricultural needs. Thus, a study to assess the fecal as well as physicochemical contamination level in groundwater of the region is the need of the hour.

\section{Materials and Methods}

\section{Ethical approval}

No ethical approval was required as no live animals were used in this study. The study was done on water samples collected as per the standard collection methods.

\section{Sampling site}

The present investigation was conducted in Brij region comprising the holy city of Mathura and the city of Taj Mahal, Agra. Mathura district is located on the latitudes $27.41^{\circ}$ North and longitudes $77.41^{\circ}$ East with an average population of $2,541,894$, situated at altitude of $287 \mathrm{~m}$ having an area of $3329.4 \mathrm{~km}$. Agra is situated between $27.11^{\circ}$ latitude North and 78.0-78. $2^{\circ}$ longitude East on the bank of Yamuna river. It is situated at an altitude of $171 \mathrm{~m}$ above the sea level and has a population of $1,760,285$ approximately.

\section{Sampling}

To assess the groundwater quality, a total of 60 water samples from handpumps/borewells/submersibles/wells were collected from six sites, viz., G1 (Maath/Raya), G2 (Goverdhan/Barsana/Vrindavan), G3 (Agra), G4 (Mathura), G5 (Baldeo), and G6 (Refinery and nearby areas), ( $\mathrm{n}=10$ for each) from December 2013 to December 2015. For physicochemical analysis, the water samples were collected in $1 \mathrm{~L}$ polypropylene bottles and in $500 \mathrm{ml}$ sterile autoclaved glass bottles (Axiva) for microbiological analysis, taking all hygienic precautions, brought to the laboratory on ice and processed within 4-6 h [13].

\section{Physicochemical analysis}

The $\mathrm{pH}$ of the water samples was determined by the Hi Media $\mathrm{pH}$ indicator paper strip (Hi Media, Mumbai) at the site of sample collection. The taste was analyzed by a panel of people at the Department of VPH, C.V.Ss, DUVASU, Mathura. Turbidity analyzed by water field test kit (multiparameter) technology (High Media, Mumbai), and total dissolved solids (TDS) were determined by water and soil analysis kit (Model No. LT-61-Scientech Lab. Pvt. Ltd., Delhi). Titration method was used to determine total hardness (TH). The chloride, fluorides, nitrate, and iron content were estimated using the Octo Aqua Test kit WT023 (Hi Media, Mumbai).

\section{Standard plate count (SPC) and most probable num- ber (MPN) test}

It was performed as per the method of Edward and Ewing [14] and Cruickshank et al. [15]. Water samples were thoroughly shaken, and each sample was analyzed in triplicate after making appropriate dilutions using $\mathrm{NaCl}$ solution $(0.85 \mathrm{~g} / \mathrm{L})$. With a sterile pipette, $1 \mathrm{ml}$ of each dilution and undiluted sample was transferred to sterile Petri plates. Molten and cooled nutrient agar (at $44-44.5^{\circ} \mathrm{C}$ ) was poured into each Petri plate. The plates were rotated gently to mix the medium and the sample thoroughly. Duplicate plates were made for each dilution. The agar was allowed to solidify for $15-20 \mathrm{~min}$ and then placed in incubator at $37^{\circ} \mathrm{C}$ for $48 \mathrm{~h}$. After the stipulated time, colony-forming units (CFUs) in the plates were counted with the help of digital colony counter (Scientech, India). Average of duplicate plates was taken and multiplied with the reciprocal of the dilution used, which gave SPC as number of bacterial CFU/ $\mathrm{ml}$ of the water sample.

$\mathrm{CFU} / \mathrm{ml}=$ Average number of colonies counted $\times$ Reciprocal of the dilution factor

The MPN test was performed using five tubes method as per the protocol and the results were interpreted using statistical table [16]. The water samples in which there was no acid and gas formation were recorded as negative for MPN.

\section{Isolation of $E$. coli}

All the 60 water samples of ground water were processed for isolation of E. coli within 4-6 h of sampling according to Sojka [17] and Edward and 
Ewing [14]. Enrichment was done in modified trypticase soya agar broth supplemented with $10 \mathrm{mg} / \mathrm{L}$ of acriflavin and later streaked onto MacConkey lactose agar plates and incubated at $37^{\circ} \mathrm{C}$ for $24 \mathrm{~h}$. Lactose fermenting pink, smooth round colonies were then streaked onto eosin methylene blue agar plates (selective plating) and incubated at $37^{\circ} \mathrm{C}$ for $24 \mathrm{~h}$. Clear blackish colonies with unmistakable greenish metallic sheen were tentatively considered to be E. coli, further confirmed by morphological (gram staining technique) and biochemical characteristics [18,19] (Hi Media Rapid Biochemical Identification Kit). All the biochemically confirmed $E$. coli isolates were streaked onto MUG-Sorbitol agar (Hi Media) and incubated at $37^{\circ} \mathrm{C}$ for $24 \mathrm{~h}$. Colonies showing nonfluorescence under ultraviolet rays were tentatively considered to be E. coli $\mathrm{O} 157: \mathrm{H} 7$.

\section{Congo red $(\mathrm{CR})$ dye binding assay for pathogenic E. coli}

CR dye binding assay was performed as per the method of Berkhoff and Vinal [20]. All the E. coli were streaked on CR agar medium comprising trypticase soya agar enriched with $0.05 \% \mathrm{CR}$ dye and $0.15 \%$ bile salts and incubated at $37^{\circ} \mathrm{C}$ for $24 \mathrm{~h}$. The plates were further incubated at room temperature for additional $48 \mathrm{~h}$ and $72 \mathrm{~h}$. The CR-positive isolates produced brick red colonies after 48-72 $\mathrm{h}$ on incubating at room temperature, while CR negative did not bind the dye and produced white or gray colored colonies on CR medium.

\section{Antibiogram of E. coli isolates and assessment of ESBL producers}

In vitro, antibiogram of all the $16 \mathrm{E}$. coli isolates was performed by disc diffusion technique against 20 commonly used antibiotics (Hi Media) in the treatment of animals [21,22], viz., levofloxacin (LE -5 $\mu \mathrm{g}$ ), cefixime (CFM- $5 \mu \mathrm{g}$ ), amoxicillin (AMS $-30 / 15 \mu \mathrm{g}$ ), ofloxacin (OF -5 $\mu \mathrm{g}$ ), ciprofloxacin (CIP - $30 \mu \mathrm{g}$ ), cotrimoxazole (COT - $23 \mu \mathrm{g}$ ), chloramphenicol $(\mathrm{C}-30 \mu \mathrm{g})$, ampicillin-salbactum (A/S - 10/10 $\mu \mathrm{g})$, gentamicin (GEN - $10 \mu \mathrm{g})$, cefuroxime (CXM - $30 \mu \mathrm{g})$, amoxicillin-clavulnic acid (AMC - $30 \mu \mathrm{g}$ ), trimethoprim (TR - $10 \mu \mathrm{g}$ ), erythromycin (E - $15 \mu \mathrm{g})$, amikacin (AK-10 $\mu \mathrm{g}$ ), enrofloxacin (EX - $10 \mu \mathrm{g}$ ), norfloxacin (NX - $10 \mu \mathrm{g})$, streptomycin (S - $10 \mu \mathrm{g}$ ), imipenem (IE - 10/750 $\mu \mathrm{g}$ ), cefoperazone (CPZ -75 $\mu \mathrm{g}$ ) andcefotaxime/clavulanic acid (CEC- $30 \mu \mathrm{g})$. A loopful of pure culture for each test isolate was transferred into a test tube containing $5 \mathrm{ml}$ of nutrient broth medium. The broth culture was incubated at $37^{\circ} \mathrm{C}$ until light to moderate turbidity develops. Inoculum's turbidity was compared with that of standard $0.5 \mathrm{McF}$ arland. After incubation, the test isolate culture was spun at $5000 \mathrm{rpm}$ for $5 \mathrm{~min}$, to obtain a pellet which was later dissolved using $1 \mathrm{ml}$ of sterile normal saline solution. Plates of Mueller-Hinton agar were seeded with about $1 \mathrm{ml}$ of inoculums by a sterile swab. Antibiotic discs were placed approximately $2.5 \mathrm{~cm}$ apart and pressed down to ensure complete contact with the agar surface.
The plates were incubated overnight at $37^{\circ} \mathrm{C}$. The zones of inhibition diameter were measured for each antibiotic, initially for quality control strain and then for the test strains. The results were compared with the interpretative chart given by the manufacturer, and the test antibiotic was graded as sensitive, resistant or intermediate for respective antibiotics. ESBL producing $E$. coli isolates were phenotypically characterized by double disc synergy test as per the recommended method [22].

\section{Statistical analysis}

The data were statistically processed and analyzed by one-way ANOVA and mean \pm significant error using Statistical Package Social Science version 16 software, packaged and developed as per the procedure of Snedechor and Cochran [23]. Duncan's multiple range tests were determined at $5 \%$ and $1 \%$ level of significance [24].

\section{Results}

Physicochemical properties of ground water $(n=60)$

The values of measured physicochemical parameters are shown in Table-1 (Figures-1 and 2). Most of the samples exceeding the limits were alkaline. The highest mean $\mathrm{pH}$ was recorded at $\mathrm{G} 3$ and the lowest at G1. The mean $\mathrm{pH}$ values of G3, G5, and G2 differed highly significantly from $\mathrm{pH}$ values of $\mathrm{G} 4, \mathrm{G} 1$, and G6 $(\mathrm{p}<0.01)$ (Table-1: Figure-2). All the water samples from G5 and G1 were colorless and odorless; however, none of the samples from any area was sweet enough to be used for drinking purpose as such. In G4 and G6, 40\% (4/10) and 60\% (6/10) sample had a distinct odor whereas $50 \%(5 / 10)$ samples from G2 were yellowish in color and had a salty odor. There was no significant difference between the turbidity content of water samples from different sites $(p>0.05)$ (Table-1: Figure-2). Considerably high TDS values were recorded with maximum value at $9000 \mathrm{ppm}$. TDS values of water from G3, G2 and G5 differed significantly from G4 and G6 and G1 $(\mathrm{p}<0.05)$ (Table1: Figure-1). Nine (15\%) of the samples exceeded the maximum allowable limit of $600 \mathrm{mg} / \mathrm{L}$ of TH set by BIS. There was no significant difference between the values of TH in water samples from all the six areas $(p>0.05)$ (Table-1: Figure-1). The chloride and fluoride levels were overall high with chloride values up to $3250 \mathrm{mg} / \mathrm{L}$ from $\mathrm{G} 5$ and fluoride up to $2.5 \mathrm{mg} / \mathrm{L}$ especially from G6. There was highly significant difference between G3, G4, G2, G1and G6 and G5 $(p<0.01)$ in case of chloride but no significant difference between fluoride content within different areas $(p>0.05)$ (Table-1: Figure-1). The nitrate content was also toward higher side with significant difference present between water samples from $\mathrm{G} 2$ and rest of the sites (G1, G3, G4, G5 and G6) $(\mathrm{p}<0.05)($ Table-1). The iron content was within normal range, however, significant difference was observed in iron values between (G2, G6) and (G1, G3, G4 and G5) $(\mathrm{p}<0.05)$ (Table-1: Figure-2). 


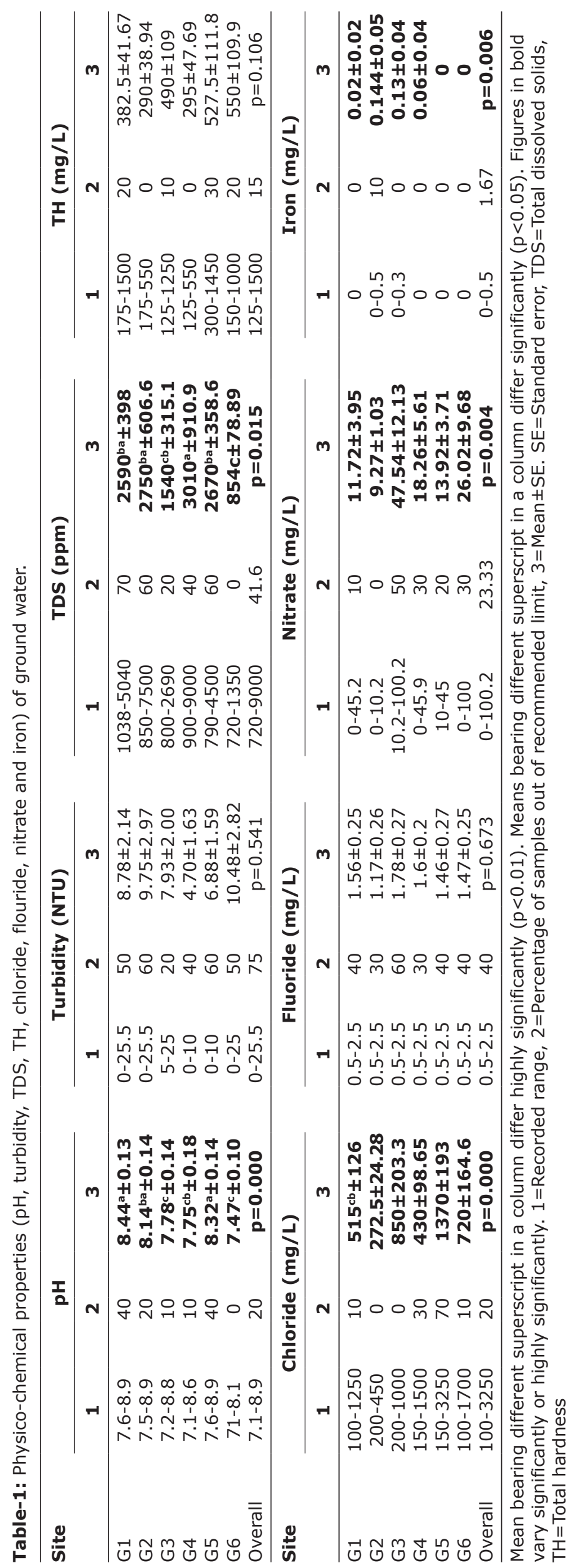




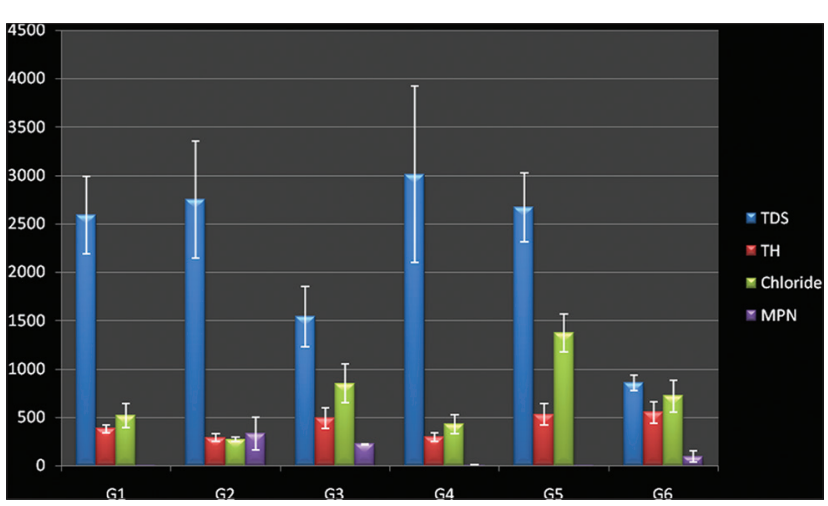

Figure-1: Physicochemical and microbiological parameters of ground water (total dissolved solids, total hardness, chloride, most probable number).

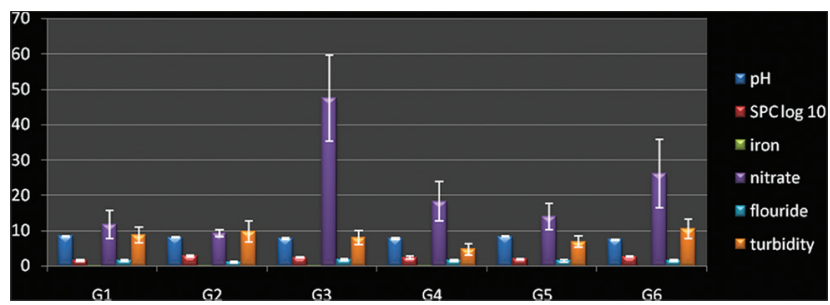

Figure-2: Physico-chemical and microbiological parameters of ground water $(\mathrm{pH}$, standard plate count, iron, nitrate, fluoride, turbidity).

\section{Microbiological qualities of ground water}

There was considerable contamination in groundwater of the area with highest SPC value observed to be $3500 \mathrm{CFU} / \mathrm{ml}$ and 40 (66.67\%) samples exceeding the maximum permissible level (MPL) of $<100 \mathrm{CFU} / \mathrm{L}$ recommended by BIS. SPC values of samples from (G2 and $\mathrm{G} 4)$ differed significantly from that of (G1, G6) and (G3, G5) $(\mathrm{p}<0.05)$ (Table-2: Figure-2). High coliform contamination was evident by high MPN values up to $>1600$ coliforms in many samples especially at G2, whereas G3 and G5 had lowest contamination level. A significant difference was observed in MPN values between water samples from (G2, G1, and G6) and (G3, G4, and G5) $(\mathrm{p}<0.05)$ (Table-2: Figure-1). The overall 16 E. coli $(26.67 \%)$ were isolated in all the 60 groundwater samples collected in this study of which only $3(18.75 \%)$ produced red colonies on CR agar indicating their pathogenic nature (Table-2). None of the confirmed $E$. coli isolates produced nonfluorescent colonies on MUG sorbitol agar indicating the absence of O157: H7 serogroup.

\section{Antibiogram of $E$. coli isolates}

Antibiogram of all the $16 \mathrm{E}$. coli isolates was performed against 20 most commonly used antimicrobials drugs. Only two E. coli $(12.5 \%)$ were ESBL positive. Overall, the isolates were highly sensitive to cefotaxime-clavulanic acid (81.25\%) and imipenem $(68.75 \%)$ and highly resistant to amoxicillin (75\%) and erythromycin (81.25\%). Intermediate sensitivity was shown against gentamicin $(93.75 \%)$, cefperazone (68.75\%), levofloxacin $(68.75 \%)$, ofloxacin $(68.75 \%)$, norfloxacin and enrofloxacin $(68.75 \%)$. Of the 16 isolates tested, $12(75 \%)$ were found to be multi-drug resistant (MDR) with an MDR Index (MDRI) $>20 \%$ including four isolates (25\%) having MDRI of $>50 \%$. The MDRI was calculated by dividing the number of antibiotics to which isolate was resistant by the total number of antibiotics to which the isolate was exposed (Table-3) [25].

\section{Discussion}

The collected groundwater samples were slightly alkaline (7.1-8.9) in accordance to values recorded in Aligarh (7.31-8.48) by Perween and Fatima [26]. Ashfaq and Ahmad [27] found a pH range of 6.4-7.9 in Agra and 6.3-8.7 in Mathura [28], respectively. Ahmed [29] found $\mathrm{pH}$ values in Mathura to be slightly less than the values in this study (7.11-8.11). The quality of groundwater varies from place to place with the depth of water table and is primarily governed by the extent and composition of dissolved solids present in it $[16,30]$. Exposure to highly alkaline water might cause irritation to eye, skin, and mucous membrane [31]. Acidic $\mathrm{pH}$ in well water was reported by Gopinath et al. [32] from 10 different locations of Kanakkary Panchayath, Kottayam District, Kerala. The $\mathrm{pH}$ of open dug well water in Ethiopia was acidic with $27.3 \%$ samples having values below the WHO limit [33]. Most of the samples were free from any disagreeable color but $40 \%$ and $68 \%$ samples from G4 and G6 had distinct metallic odor. Similar results were obtained by Ahmed [29]. He also found 15\% of samples in G1, 50\% in G4 and 80\% samples from G5 to be sweet in taste, whereas in this study, all the samples were salty to taste. This disparity might be due to different locations or seasons of sample collection in a particular area as values change with respect to geographical and topographical locations or smaller sample size $(n=10)$ in this study. Water gets turbid due to soil runoff, the presence of organic and inorganic matter and prevalence of harmful (pathogenic) microorganisms [34]. In our study, turbidity of $75 \%$ samples was more than the desired, hence not suitable for drinking and other purposes. Several authors have found turbidity in this area to be lower than that observed in this study [26-28,16,30]. The mean turbidity values in a study from Nigeria [35] were almost similar to the results obtained in this study. The consumption of highly turbid waters may constitute a health risk as excessive turbidity can protect pathogenic microbes from effect of disinfectants and also stimulate the growth of bacteria during storage [36].

Fluctuations in TDS values are mainly because of dissolved inorganic salts such as carbonates, bicarbonates, phosphates, and sulfates. In Mathura district, water logging and salinity in groundwater have become a universal problem. The general quality of water is brackish with $85 \%$ samples having TDS above $1000 \mathrm{mg} / \mathrm{L}$ [37]. We found high TDS values similar to the reports of Rawat et al. [37] and Tripathi 
Table-2: Microbiological properties (SPC, MPN) of groundwater.

\begin{tabular}{|c|c|c|c|c|c|c|c|c|c|}
\hline \multirow[t]{2}{*}{ Site } & \multirow{2}{*}{$\begin{array}{l}\text { Number of } \\
\text { samples }\end{array}$} & \multicolumn{3}{|c|}{ SPC } & \multicolumn{3}{|c|}{ MPN } & \multirow[t]{2}{*}{ E. coli } & \multirow[t]{2}{*}{ Pathogenic E. coli } \\
\hline & & 1 & 2 & 3 & 1 & 2 & 3 & & \\
\hline $\mathrm{G} 1$ & 10 & $0-500$ & 30 & $1.60^{c} \pm 0.27$ & $0-25$ & 10 & $3.2^{b} \pm 2.52$ & $2(20)$ & 0 \\
\hline $\mathrm{G} 2$ & 10 & $150-3500$ & 100 & $2.83^{a} \pm 0.17$ & $0-1600$ & 70 & $334.6^{a} \pm 169.51$ & $2(20)$ & 1 \\
\hline G3 & 10 & $60-1250$ & 70 & $2.34^{\text {ba }} \pm 0.14$ & $0-1600$ & 50 & $221.2^{\mathrm{ba}} \pm 162.43$ & $3(30)$ & 1 \\
\hline G4 & 10 & $5-3000$ & 70 & $2.40^{\mathrm{ba}} \pm 0.30$ & $0-25$ & 20 & $4.9^{b} \pm 2.79$ & 0 & 0 \\
\hline G5 & 10 & $30-300$ & 40 & $2.0^{\mathrm{ca}} \pm 0.10$ & $0-10$ & - & $3.2^{\mathrm{b}} \pm 1.31$ & 0 & 0 \\
\hline G6 & 10 & $75-2000$ & 90 & $2.63^{a} \pm 0.13$ & $0-550$ & 90 & $95^{\mathrm{ba}} \pm 57.14$ & $9(90)$ & 1 \\
\hline overall & 60 & $0-3500$ & 66.67 & $P=0.001$ & $0-1600$ & 40 & $P=0.094$ & $16(23.3)$ & $3(5)$ \\
\hline
\end{tabular}

Values in bracket are in percentages. Mean bearing different superscript in a column differ highly significantly $(p<0.01)$. Means bearing different superscript in a column differ significantly $(p<0.05)$. Figures in bold vary significantly or highly significantly. 1 =Recorded range, $2=$ Percentage of samples out of recommended limit, $3=$ Mean $\pm S E$. SPC $=S t a n d a r d ~ p l a t e$ count, MPN=Most probable number

Table-3: Occurrence of MDR in E. coli isolates.

\begin{tabular}{lccc}
\hline $\begin{array}{l}\text { E. coli } \\
\text { isolate }\end{array}$ & $\begin{array}{c}\text { Resistance } \\
\text { to number of } \\
\text { antibiotics out } \\
\text { of } \mathbf{2 0}\end{array}$ & MDRI (\%) & $\begin{array}{c}\text { Highly resistant } \\
\text { (MDRI } \mathbf{2 0 \% )}\end{array}$ \\
\hline 1 & 10 & 50 & + \\
2 & 6 & 30 & + \\
3 & 12 & 60 & + \\
4 & 12 & 60 & + \\
5 & 6 & 30 & + \\
6 & 4 & 20 & - \\
7 & 6 & 30 & + \\
8 & 5 & 25 & + \\
9 & 3 & 15 & - \\
10 & 2 & 10 & - \\
11 & 9 & 45 & + \\
12 & 3 & 15 & - \\
13 & 4 & 20 & - \\
14 & 3 & 15 & + \\
15 & 7 & 35 & + \\
16 & 6 & 37.5 & \\
\hline
\end{tabular}

MDRI $=$ Multi-drug resistance index, $E$. coli=Escherichia coli

and Thawkar [38], who recorded TDS to be in the range of 570-6692 and 1420-6740 $\mathrm{mg} / \mathrm{L}$ in Mathura, respectively. Ahmed [29] found TDS values to be lower than this study. Thus, ground water of Mathura is not palatable due to excess salt and mineral content in it and has been shown to increase mortality from all categories of ischemic heart diseases and acute myocardial infarction [39]. The ground water of this region was found to be considerably hard (125$1500 \mathrm{mg} / \mathrm{L}$ ) with $15 \%$ samples exceeding the maximum limit of $600 \mathrm{mg} / \mathrm{L}$ of BIS. Lesser values of TH have been recorded in earlier studies from Mathura and Agra $[16,27,28,30]$. In contrast, very high TH values up to $6250 \mathrm{mg} / \mathrm{L}$ in bore well waters in Mathura have also been reported [38].

Chlorides exceeding $250 \mathrm{mg} / \mathrm{L}$ impart salty taste to water and cause laxative effects [40]. Chlorides are the most stable components in water and their concentration is largely unaffected by most natural physicochemical and biochemical processes. Hence, the value of its concentration in water is a useful measure to assess water quality [35]. Many studies in Brij region including this study have indicated high chloride levels in the groundwater $[28,29,37,38]$ thereby making treatment of water mandatory before consumption. Fluoride is endemic for Indian subcontinent with $65 \%$ of Indian villages in 17 states, being exposed to fluoride risk [41]. These higher fluoride levels in groundwater in Indian continent are associated with igneous and metamorphic rocks [42] and have now become one of the most important toxicological and geoenvironmental issues in Brij region. High values of fluoride have been reported all over India $[43,44]$. A study by Rawat et al. [37] found fluoride level up to $4.6 \mathrm{mg} / \mathrm{L}$ in shallow ground water at Shahpur, Mathura, with an average of $3 \mathrm{mg} / \mathrm{L}$ in a large part of Mathura. Ahmed [29] recorded a range of 0.5-2 mg/L fluoride content in groundwater of Mathura. Thus, our findings corroborate with these values. Leaching of chemicals, fertilizer, animal manure and pollution from septic and sewage discharges are the main sources of nitrates in water. Although it is considered non-toxic, a high concentration in drinking water is an environmental health concern because it can cause methemoglobinemia or blue baby syndrome in infants, causing death in extreme cases. Nitrate concentration above the MPL of $45 \mathrm{mg} / \mathrm{L}$ is reported in 11 states of India, covering 95 districts. Overall nitrate in all groundwater samples in the present study was found to be $0-100.2 \mathrm{mg} / \mathrm{L}$. This finding is in agreement with the observations of Rawat et al. [37] who recorded high values of nitrates up to $108 \mathrm{mg} / \mathrm{L}$ in groundwater samples from Mathura. In another study indicating groundwater pollution due to urban wastes in Delhi based at Delhi, $57 \%$ of samples showed values higher than $45 \mathrm{mg} / \mathrm{L}$ with $13 \%$ samples exceeding $100 \mathrm{mg} / \mathrm{L}$ [45]. These high levels have been attributed to heavy use of nitrogenous fertilizers, cattle waste dumping, waste water disposal, pit latrines, etc., in few agriculturally intensive areas in India [46-49].

The water samples did not have detectable iron content in them. Pandey [30] and Ahmed [29] also found iron to be absent or in trace amounts in ground water samples of Agra and Mathura, respectively. Iron in water can affect the flavor of water and promotes the growth of iron bacteria in water [50]. Similarly, permissible limits of iron were found in water samples in Namdayal rural area of Kurnool district 
Andhra [51] and well waters of Abokuta, Nigeria [52]. However, iron level in drinking waters of Renigunta near Tirupati, Andhra, ranged from 0.16 to $0.71 \mathrm{mg} / \mathrm{L}$ with many samples exceeding the desirable range but lying within the MPL [53].

In this study, values of SPC and MPN of coliform indicated high microbial especially fecal contamination in ground water. Coliform count of $40 \%$ samples exceeded the MPL of $\leq 10$ coliforms $/ 100 \mathrm{ml}$ for untreated water. Contamination was evident especially in G1 and G2 sites, whereas none of the samples from G5 were contaminated. Ahmed [29] also found the microbial quality of groundwater of this area to be unsatisfactory. Drinking water from Junagadh, Gujarat, showed heavy presence of coliforms up to $>2400 / 100 \mathrm{ml}$ [54], but the pollution level of groundwater was much less in Bargarh district, Orissa, India [55]. In Hyderabad, water of protected wells had MPN in excess of 800 and was not potable [56]. In Egypt also, well water samples had high level of total coliforms and fecal coliforms [57].

Water is a very efficient vehicle for the dissemination of $E$. coli and has been implicated in various outbreaks worldwide [58-60]. In this study, out of 60 groundwater samples, $16 \mathrm{E}$. coli were isolated (26.7\%) indicating fecal contamination of groundwater of the area. Singh [61] who isolated 4 E. coli in 16 bore well waters (25\%) from Mathura. However lesser load of $9.23 \%$ was found by Ahmed [29], in groundwater samples from Mathura but no pathogenic E. coli could be isolated. CR assay is used as a phenotypic marker to distinguish between virulent invasive and avirulent E. coli. In this study, out of $16 \mathrm{E}$. coli, three $(18.75 \%)$ were pathogenic as they produced red colonies on CR agar. Berkhoff and Vinal [20] established a direct correlation between ability of clinical isolates of $E$. coli to bind CR dye and their ability to cause septicemic infection in chicken.

Antibiotic resistance in E. coli has been globally identified in isolates from environmental, animal and human sources [62] which might be a consequence of the non-judicious use of antimicrobials in animals, bringing about chromosomal mutations and hence phenotypic changes $[63,64]$. Various workers all over the globe have reported the presence of antibiotic resistant E. coli in waters [65-69]. In this study, $12(75 \%)$ isolates were found to be highly resistant with a MDRI $>20 \%$ including 4 isolates $(25 \%)$ having MDRI of $>50 \%$. MDR (3-6 antimicrobials) was seen in $62.96 \%$ of $E$. coli isolates from drinking water [70]. The prevalence of multiple-antibiotic-resistant $E$. coli was observed in Dutch surface and waste water samples [71], Portugal fountains [72] and Romanian rivers [73]. A high incidence of ESBL E. coli has been reported by Doughari et al. [74] and George et al. [75] in environmental isolates. Presence and persistence of pathogenic ESBL E. coli in surface, ground and drinking water samples, is a matter of great public health concern because water may serve as a potential source of these resistant bacteria to humans.

\section{Conclusions}

From the findings of the study, it is evident that groundwater of Brij region is heavily contaminated with various salts, organic and inorganic impurities. The occurrence of MDR E. coli in these groundwater samples is a matter of great public health concern as it might serve as a source of drug resistant $E$. coli to humans and animals which consume these waters apart from other health problems which might be there due to the presence of other impurities. As the region is a prominent tourist destination, this problem becomes graver. Thus, it is suggested that groundwater should be consumed only after proper treatment and a detailed survey should be carried out with larger sample size to assess the real extent of the problem.

\section{Authors' Contributions}

Parul, AKV, and UJ executed the study design and analyzed the data. RS and RM helped in collection of samples and laboratory testing of them along with analysis of data. BS drafted and revised the manuscript with the help of JKY, AKV, and UJ. All authors read and approved the final manuscript.

\section{Acknowledgments}

This work was a part of thesis work done in the Departments of Epidemiology and Veterinary Public Health, College of Veterinary Science and Animal Husbandry, UP Pt Deen Dayal Upadhyay Veterinary University, DUVASU, Mathura. The authors would like to thank Vice-Chancellor and Dean, Dean PG, DUVASU, Mathura, for providing all the facilities necessary for the work.

\section{Competing Interests}

The authors declare that they have no competing interests.

\section{References}

1. WHO. (2015) Guidelines for Drinking - Water Quality. $4^{\text {th }}$ ed. WHO Press, Geneva, Switzerland.

2. WHO and UNICEF. (2013) Progress on Sanitation and Drinking Water. 2013 Update. World Health Organization, Geneva.

3. Pons, W., Young, I., Truong, J., Jones-Bitton, A., McEwen, S., Pintar, K. and Papadopoulos, A. (2015) A systematic review of waterborne disease outbreaks associated with small non-community drinking water systems in Canada and the United States. PLoS One, 10(10): e0141646.

4. Aremu, M.O., Olaofe, O., Ikokoh, P.P. and Yakubu, M.M. (2011) Physicochemical characteristics of Strem, well and borehole water sources in Eggon, Nasarawa State, Nigeria. J. Chem. Soc. Nig., 36(1): 131.

5. Hornsby, A.G. (2009) Soil and water science. Available from: http://www.eda/yan.uf.e3du/ss.299. Accessed on 12-04-16

6. Brüssow, H., Canchaya, C. and Hardt, W.D. (2004) Phages and the evolution of bacterial pathogens: From genomic rearrangements to lysogenic conversion. Microbiol. Mol. Biol. Rev., 68: 560-602. 
7. Nataro, J.P. and Kaper, J.B. (1998) Diarrheagenic Escherichia coli. Clin. Micro Rev., 11(1): 142.

8. Blankenhorn, D., Phillips, J. and Slonczewski, J.L. (1999) Acid-and base-induced proteins during aerobic and anaerobic growth of Escherichia coli revealed by two-dimensional gel electrophoresis. J. Bacteriol., 181: 2209-2216.

9. PEN. (2006b) Pathogenicity, Virulence and Emerging Pathogenic Escherichia coli [Online]. Pathogenic Escherichia coli Network. Available from: http://www. pen-europe.eu/images/site/assets/Epidemiology-andTransmission.pdf. Accessed on 21-02-2016.

10. Kaper, J.B., Nataro, J.P. and Mobley, H.L. (2004) Pathogenic Escherichia coli. Nat. Rev. Microbiol., 2(2): 123-140.

11. Weintraub, A. (2007) Enteroaggregative Escherichia coli: Epidemiology, virulence and detection. J. Med. Microbiol., 56: 4.

12. Barguigua, A., Otmani, F.E., Talmi, M., Bourjilat, F., Haouzane, F., Zerouali, K. and Timinouni, M. (2011) Characterization of extended-spectrum b-lactamase-producing Escherichia coli and Klebsiella pneumoniae isolates from the community in Morocco. J. Med. Microbiol., 60: 1344.

13. Park, K. (2011) Park Textbook of Preventive and Social Medicine. $21^{\text {st }}$ ed. M/S Banarsidas Bhanot, Jabalpur. p32.

14. Edward, P.R. and Ewing, W.H. (1972) Identification of Enterobacteriaceae. Burgess Publishing Company, Minnesota, USA.

15. Cruickshank, R., Duguid, J.P., Marrmion, B.P. and Swain, R.H.A. (1975) Medical Microbiology. 12 $2^{\text {th }}$ ed., Vol. II. Churchill Livingstone, Edinburg, London, New York.

16. APHA. (1998) Standard Methods for Examination of Water and Waste Water. $20^{\text {th }}$ ed. American Public Health Association, New York. p81-85.

17. Sojka, W.J. (1965) Escherichia coli in domestic animals and poultry. Review Series No. 7 of the Commonwealth Bureau of Animal Health. Commonwealth Agriculture Buraeu, Farnham Royal, UK.

18. Ewing, W.H. (1986) Identification of Enterobacteriaceae. $4^{\text {th }}$ ed. Elsevier, Netherlands.

19. Ahmad, M.D., Hashmi, R.A., Anjum, A.A., Hanif, A. and Ratyal, R.H. (2009) Drinking water quality by the use of Congo red medium to differentiate between pathogenic and non-pathogenic E. coli at poultry farms. J. Anim. Plant Sci., 19(2): 108.

20. Berkhoff, H.A. and Vinal, A.C. (1986) Congo red medium to distinguish between invasive and non-invasive Escherichia coli pathogenic for poultry. Avian Dis., 30(1): 117.

21. Bauer, A.W., Kirby, W.M.M., Sherries, J.S. and Truck, M. (1966) Antibiotic susceptibility testing by a standard single disc method. Am. J. Clin. Pathol., 45: 493-496.

22. Clinical and Laboratory Standards Institute (Formerly National Committee for Clinical Laboratory Standards). (2011) Performance Standards for Antimicrobial Susceptibility Testing; Fifteenth Informational Supplement, M100-S15. CLSI, Wayne, PA, USA.

23. Snedecor, G.W. and Cochran, W.G. (1989) Statistical Methods. $8^{\text {th }}$ ed. Iowa State Press, Ames.

24. Duncan, D.B. (1955) Multiple range and multiple F-tests. Biometrics, 11: 1-42.

25. Chandran, A., Hatha, A.A.M., Varghese, S. and Monisheeza, K. (2008) Prevalence of multiple drug resistant Escherichia coli serotypes in a tropical estuary, India. Microbes Environ., 23(2): 153.

26. Perween, S. and Fatima, U. (2015) Study of groundwater quality by the assessment of physico-chemical parameters and water quality index in Aligarh, Uttar Pradesh. J. Chem. Pharm. Res., 7(5): 761

27. Ashfaq, A. and Ahmed, F. (2014a) Quality assessment of groundwater at Agra district, India. Int. J. Curr. Res., 2(8): 304-308.

28. Ashfaq, A. and Ahmed, F. (2014b) Qualitative monitoring of underground water quality of Mathura City. Indian $J$. Fundam. Appl. Life Sci., 4(3): 208.

29. Ahmed, W. (2014) Quality analysis of groundwater and recreational water sources in Brij region with special reference to E. coli O157:H7. M.V.Sc Thesis Submitted to UP Pandit Deen Dayal Upadhyay Pashuchikitsa Vigyan Vishwavidyalaya Evam Gau Anusandhan Sansthan (DUVASU), Mathura.

30. Pandey, R.K. (2016) Quantitative studies on physico-chemical properties of ground water of Agra (Uttar Pradesh) India. World J. Biol. Med. Sci., 3(1): 132.

31. WHO. (1986) World Health Organization Working Group. Health impact of acidic deposition. Sci. Total Environ., 52: 157.

32. Gopinath, A., Chandran, R.P., Vysakhi, M.V. and Anu, A.S. (2012) Physical and bacteriological quality of well water samples from Kanakkery Panchayath, Kottayam district, Kerala State, India. Int. J. Plant Anim. Environ. Sci., 2(3): 133-138.

33. Tsega, N., Sahile, S., Kibret, M. and Abera, B. (2013) Bacteriological and physico-chemical quality of drinking water sources in a rural community of Ethiopia. Afr. Health Sci., 13(4): 1156

34. Das, A.K. and Shrivastva, N.P. (2003) Ecology of Sarni Reservoir (M.P.) in the context of fisheries. Pollut. Res., 22: 533.

35. Ezeribe, A.I., Oshieke, K.C. and Jauro, A. (2012) Physicochemical properties of well water samples of some villages in Nigeria with cases of stained and mottled teeth. Sci. World J., 7(1): 1.

36. Zwikomborero, H. (2005) An assessment of water quality of drinking water in rural districts in Zimbabwe an assessment of the water quality of drinking water in rural districts in Zimbabwe. The case of Gokwe South, Nkayi, Lupane, and Mwenezi districts. Phys. Chem. Earth, 30(11-16): 859.

37. Rawat, K.S., Mishra, A.K., Sehgal, V.K. and Tripathi, K. (2012) Spatial variability of ground water quality in Mathura district (Uttar Pradesh, India) with geostatistical method. Int. J. Remote Sens. Appl., 2(1): 1-9.

38. Tripathi, C.N. and Thawkar, B. (2013) Ground water quality assessment for agricultural and domestic purposes in Hindustan College of science and technology campus Farah Mathura, India. Int. J. Eng. Res. Technol., 2(4): 778-789.

39. Meyers, D. (1975) Mortality and water hardness. Lancet, 1: 398 .

40. Chand, D. (1999) Fluoride and human health-causes for concern. Indian J. Environ. Prot., 19(2): 81.

41. UNICEF. (1999) States of the Art Report on the Extent of Fluoride in Drinking Water and the Resulting Endemicity in India. Report by Fluorosis and Rural Development Foundation for UNICEF, New Delhi.

42. Sundaraiah, R., Sakram, G., Bhoopathi, V.V., Kumar, L.D. and Sudarshan, V. (2014) Fluoride distribution in the groundwater of Kalwakurthy area, Mahabubnagar District, Andhra Pradesh, India. Int. J. Rec. Sci. Res., 5(2): 4388.

43. Meenakshi, Garg, V.K., Kavita, Renuka. and Malik, A. (2004) Groundwater quality in some villages of Haryana, India: Focus on fluoride and fluorosis. J. Hazard Mater, 106B: 85-97.

44. Yadav, R., Yadav, R.N., Chandrawat, M.P.S. and Sharma, S.K. (2008) Assessment of fluoride content $\mathrm{pH}$ and TDS in potable water of Alwar city: An environmental concern. RJC Rasayan J. Chem., 1(4): 929.

45. Kumar, L. (2005) A Study of Nitrate Concentration in Ground Water of Delhi, India. M. Phil Thesis Submitted to LNJN NICFS, Government India, New Delhi.

46. Bijay-Singh, Y., Singh, G.S. and Sekhon, G.S. (1995) Fertilizer-N use efficiency and nitrate pollution of groundwater in developing countries. J. Contam. Hydrol., 20: $167-184$.

47. Kundu, M.C. and Mandal, B. (2008) Agriculture activities influence nitrate and fluoride contamination in drinking 
groundwater of an intensively cultivated district in India. Water Air Soil Pollut., 198(1-4): 243.

48. Suthar, S., Chhimpa, V. and Singh, S. (2009) Bacterial contamination in drinking water: A case study in rural areas of northern Rajasthan, India. Environ. Monit. Assess., 159: 43.

49. Sankararamakrishnan, N., Sharma, A.K. and Lyengar, L. (2008) Contamination of nitrate and fluoride in groundwater along the Ganges alluvial plain of Kanpur district, Uttar Pradesh, India. Environ. Monit. Assess., 146: 375-382.

50. Yagoub, A.E.A. and Ahmed, T.A. (2009) Microbiological evaluation of the quality of tap water distributed at Kahrtoum state. Res. J. Microbiol., 4(10): 355.

51. Rafi, M.K., Ramachar, T. and Umamahesh, M. (2011) A study on chemical analysis of drinking water from some communities in Nandyal rural areas of Kurnool district, Andhra Pradesh, India. Int. J. Civil Struct. Eng., 2(1): 351-358.

52. Shittu, O.B., Olaitan, J.O. and Amusa, T.S. (2008) Physicochemical and bacteriological analyses of water used for drinking and swimming purposes in Abeokuta, Nigeria. Afr. J. Biomed. Res., 11: 285.

53. Dorairaju, S.V., Rao, C.N., Raju, M.B. and Chalapathi, P.V. (2012) Chemical properties of drinking water of Renigunta Near Tirupati, Andhra Pradesh, India and its impact on human health. Curr. World Environ., 7(1): 37.

54. Vyas, V.G., Hassan, M., Vindhani, S.I., Parmar, H.J. and Bhalani, V.M. (2015) Physicochemical and microbiological assessment of drinking water from different sources in Junagadh City, India. Am. J. Microbiol. Res., 3(4): 148.

55. Mahananda, M.R., Mohanty, B.P. and Behera, N.R. (2010) Physico-chemical analysis of surface and ground water of Bargarh District, Orissa, India. IJRRAS, 2(3): 284-295.

56. Battu, P.R. and Reddy, M.S. (2009) Bacteriological examination of drinking water with reference to coliforms in Jeedimetla, Hyderabad, India. Afr. J. Biotechnol., 8(20): 5495.

57. Mostafa, A.H., Al-Wasify, R.S., Sayed, A.M. and Haroun, B.M. (2013) Microbiological and physicochemical evaluation of groundwater in Egypt. Int. J. Environ. Sust., 2(2): 1 .

58. Bopp, D.J., Saunders, B.D., Waring, A.L., Ackelsberg, J., Dumas, N., Braun-Howland, E., Dziewulski, D., Wallace, B.J., Kelly, M., Halse, T., Musser, K.A., Perry, F., Smith, P.F., Morse, D.L., Ronald, J. and Limberger, R.J. (2003) Detection, isolation and molecular subtyping of Escherichia coli $\mathrm{O} 157: \mathrm{H} 7$ and Campylobacter jejuni associated with a large waterborne outbreak. J. Clin. Microbiol., 41(1): 174

59. Olsen, S.J., Miller, G., Breuer, T., Kennedy, M., Higgins, C., Walford, J., McKee, G., Fox, K., Bibb, W. and Mead, P. (2002) A waterborne outbreak of Escherichia coli O157, H7 infections and hemolytic uremic syndrome: Implications for rural water systems. Emerg. Infect. Dis., 8: 370.

60. Hrudey, S.E., Payment, P., Huck, P.M., Gillham, R.W. and Hrudey, E.J. (2003) A fatal waterborne disease epidemic in Walkerton, Ontario: Comparison with other waterborne outbreaks in the developed world. Water Sci. Technol., 47(3): 7.

61. Singh, S. (2011) Prevalence of verotoxic E. coli in meat, meat products and water from different sources in certain areas of Uttar Pradesh. M.V.Sc Thesis Submitted to UP Pandit Deen Dayal Upadhyay Pashuchikitsa Vigyan Vishwavidyalaya Evam Gau Anusandhan Sansthan (DUVASU), Mathura
(UP), India.

62. von Heike, B. and Reinhard, M. (2005) Antimicrobial resistance of Escherichia coli and therapeutic implications. Int. J. Med. Microbiol., 295(6-7): 503.

63. Walsh, C. (2003) Antibiotics: Actions, Origins, Resistance. Washington, DC: ASM Press.

64. Reinthaler, F.F., Posch, J., Feierl, G., Wüst, G., Haas, D., Ruckenbauer, G., Mascher, F. and Marth, E. (2003) Antibiotic resistance of E. coli in sewage and sludge. Water Res., 37(8): 1685.

65. Li, X., Watanabe, N., Xiao, C., Harter, T., McCowan, B., Liu, Y. and Atwill, E.R. (2014) Antibiotic-resistant E. coli in surface water and groundwater in dairy operations in Northern California. Environ. Monit. Assess., 186: 1253.

66. Adejuwon, O.A., Bisi-Johnson, M.A., Agboola, M.A., Fadeyi, B.O. and Adejuwon, A.O. (2011) Antibiotics sensitivity patterns of Escherichia coli and Aerobacter aerogenes isolated from well water in Ile-Ife. Nig. Int. J. Med. Med. Sci., 3(5): 155 .

67. Birosova, L., Nagyova, K., Mackula, K.T. and Medvedova, A. (2015) The occurrence of antibiotic resistant Escherichia coli and Staphylococcus aureus in waste water and sludge from treatment plane in Czech Rep. Proceedings of $14^{\text {th }}$ International Conference on Environmental Science and Technology. Rhodes, Greece, 3-5, September. 2015.

68. Rashid, M., Rakib, M.M. and Hasan, B. (2015) Antimicrobial-resistant and ESBL-producing Escherichia coli in different ecological niches in Bangladesh. Infect. Ecol. Epidemiol., 5: 26712.

69. Umaru, G.A., Adamu, Z., Ishaya, D., Abubakar, Y.U., Hussaini, A., Umar, M., Adamu, S.G. and Adamu, N.B. (2005) Prevalence and antimicrobial resistance pattern of Escherichia coli in drinking waters in Jalingo Metropolis, Taraba State, North-Eastern Nigeria. Braz. J. Microbiol., 36: 217.

70. Patoli, A.A., Patoli, B.B. and Mehraj, V. (2010) High prevalence of multi-drug resistant Escherichia coli in drinking water samples from Hyderabad. Gomal J. Med. Sci., 8(1): 23.

71. Blaak, H., Lynch, G., Italiaander, R., Hamidjaja, A.R., Chets, F.M. and Husman, A.M.R. (2015) Multidrugresistant and extended spectrum beta-lactamase-producing Escherichia coli in Dutch surface water and wastewater. PLoS One, 10(6): e0127752.

72. Flores, C.E., Loureiro, L., Bessa, L.J. and da Costa, P.M. (2013) Presence of Multidrug-Resistant E. coli, Enterococcus spp. and Salmonella spp. in Lakes and Fountains of Porto, Portugal. J. Water Resour. Prot., 5: 1117.

73. Florea, A.B. (2011) Antimicrobial susceptibility of Eschericia coli isolated from Aries river (Romania) Analele Universităţii din Oradea. Fascicula Biol. Tom., XVIII(1): 34

74. Doughari, H.J., Patrick, A.N., Izanne, S.H. and Spinney, B. (2012) Virulence, resistance genes, and transformation amongst environmental isolates of Escherichia coli and Acinetobacter spp. J. Microbiol. Biotechnol., 22(1): 25.

75. George, E.A., Sankar, S., Jesudasan, M.V., Sudandiradoss, C. and Nandagopal, B. (2014) Incidence of extended spectrum beta lactamase producing Escherichia coli among patients, healthy individuals and in the environment. Indian J. Med. Microbiol., 32(2): 172. 